www.volsu.ru

DOI: https://doi.org/10.15688/nsr.jvolsu.2019.3.6

UDC 338.45:622.323

LBC 65.305.143:2-52

\title{
COMPARATIVE ANALYSIS OF OIL PRODUCTION IN RUSSIA AND ABROAD
}

\author{
Mikhail P. Lyabin \\ Volgograd State University, Volgograd, Russian Federation \\ Natalia A. Borozdina \\ Volgograd State University, Volgograd, Russian Federation \\ Margarita V. Postnova \\ Volgograd State University, Volgograd, Russian Federation
}

Alexey I. Bolkunov

Volgograd State University, Volgograd, Russian Federation

Sergey P. Butko

Volgograd Academy of the Ministry of Internal Affairs of the Russian Federation, Volgograd, Russian Federation

\section{Alina K. Postnova \\ Volgograd State University, Volgograd, Russian Federation}

Abstract. The modern oil complex of the Russian Federation makes a significant contribution to the formation of a positive trade balance and tax revenues to budgets of all levels. This resource makes up more than $16 \%$ of Russian GDP, a quarter of tax and customs revenues to budgets of all levels, and more than a third of the incoming foreign exchange revenue. The article presents the analysis of Russian companies which currently produce much less oil than west companies, except "Lukoil" company. The main reasons for the decline in production are considered to be the lack of financial resources for investment, the underdevelopment of the Russian export infrastructure, and low domestic demand for the products of the industry. At the same time, lower rates of developing existing reserves in Russia in comparison with the west can provide a much longer duration of their operation. One of the priorities for Russian companies is the availability of large oil reserves. At the same time, this advantage is largely lost due to high taxes and low prices for final products. The main disadvantages of Russian companies are considered to be a high degree of financial vulnerability and low efficiency of production activities in comparison with the leading companies of the west. However, the Russian Federation remains an undisputed world leader in oil production and export. The analytical review characterizes the Russian oil complex as a sector of fuel and energy potential and the contribution of oil production to the country's economic development, the existing resource potential of both oil fields and their number, and recently discovered oil fields. The paper estimates the cost of oil from leading oil producers and the technological capabilities of extracting oil from hard-to-reach fields and describes the resource potential of OPEC countries, Russia, and the United States. The resulting analytical conclusion is the given options for improving the innovative sphere of Russia to increase the efficiency of oil production and development of hard-to-reach oil fields.

Key words: oil production, oil companies, OPEC countries, oil fields, oil production technologies.

УДК 338.45:622.323

ББК 65.305.143:2-52

\section{СРАВНИТЕЛЬНЫЙ АНАЛИЗ ДОБЫЧИ НЕФТИ В РОССИИ И ЗА РУБЕЖОМ}

\author{
Михаил Павлович Лябин
}

Волгоградский государственный университет, г. Волгоград, Российская Федерация 


\title{
Наталья Андреевна Бороздина
}

Волгоградский государственный университет, г. Волгоград, Российская Федерация

\section{Маргарита Викторовна Постнова}

Волгоградский государственный университет, г. Волгоград, Российская Федерация

\section{Алексей Иванович Болкунов}

Волгоградский государственный университет, г. Волгоград, Российская Федерация

\section{Сергей Петрович Бутко}

Волгоградская академия Министерства внутренних дел Российской Федерации, г. Волгоград, Российская Федерация

\section{Алина Кирилловна Постнова}

Волгоградский государственный университет, г. Волгоград, Российская Федерация

\begin{abstract}
Аннотация. Современный нефтяной комплекс нашей страны вносит значительный вклад в формирование положительного торгового баланса и налоговых поступлений в бюджеты всех уровней. Состав этого ресурса составляет более $16 \%$ произведенного ВВП России, четвертую часть налоговых и таможенных поступлений в бюджеты всех уровней, а также более трети поступающей валютной выручки. В статье проведен анализ российских компаний, которые в настоящее время производят значительно меньше нефти, чем западные кроме компании «Лукойл». Основными причинами сокращения производства считается дефицит финансовых средств для инвестиций, неразвитость экспортной инфраструктуры России и низкий внутренний спрос в стране на продукцию отрасли. Вместе с тем, более низкие, чем на Западе, темпы разработки имеющихся запасов (на территории России) способны обеспечить значительно большую продолжительность их эксплуатации. Одной из приоритетных стороной российских компаний является наличие больших запасов нефти. При этом, данное преимущество в значительной степени утрачивается вследствие высоких налогов и низких цен на конечную продукцию, в которых вынуждены работать российские производители. Главными недостатками компаний России считаются большая степень финансовой уязвимости и низкая эффективность производственной деятельности по сравнению с ведущими компаниями Запада. Однако, страна остается безусловным мировым лидером по добыче и экспорту нефти. Проведенный аналитический обзор характеризует нефтяной комплекс России как сектор топливно-энергетического потенциала и вклад добычи нефти в экономическое развитие страны, имеющийся ресурсный потенциал как месторождения нефти и их число, так и недавно открытые месторождения нефти. Оценены себестоимость нефти у ведущих производителей нефти и технологические возможности добычи нефти из труднодоступных месторождений. Охарактеризован ресурсный потенциал стран ОПЕК и России, США. Результирующим аналитическим выводом являются приведенные варианты совершенствования инновационной сферы России для повышения эффективности нефтедобычи и освоению труднодоступных месторождений нефти.
\end{abstract}

Ключевые слова: добыча нефти, нефтедобывающие компании, страны ОПЕК, месторождения нефти, технологии по добычи нефти.

Современный экономический сектор экономики в области нефтедобычи является одним из наиболее устойчиво работающих производственных комплексов российской экономики. Нефтяной комплекс обеспечивает значительный вклад в формирование положительного торгового баланса и налоговых поступлений в бюджеты всех уровней. Этот вклад существенно выше доли комплекса в промышленном производстве. На его долю приходится более $16 \%$ произведенного ВВП России, четвертая часть налоговых и таможенных по- ступлений в бюджеты всех уровней, а также более трети поступающей в Россию валютной выручки $[14 ; 15]$. Такие высокие показатели связаны со значительным ресурсным и производственным потенциалом нефтяной отрасли.

В недрах России сосредоточено около $13 \%$ разведанных запасов нефти. Эти ресурсы расположены в основном на суше (примерно 3/4). Примерно $60 \%$ ресурсов нефти приходится на долю районов Урала и Сибири, что создает потенциальные возможности экспор- 
та, как в западном, так и в восточном направлениях. Экономика страны потребляет лишь менее трети добываемой нефти (включая продукты ее переработки). Основные регионы добычи - открытые еще в 1960-е и 1970-е годы западносибирские месторождения, на долю которых приходится 68,1 \% совокупной годовой добычи. Второй в стране по объему добычи нефти - Волго-Уральский регион - находится в поздней стадии разработки продуктивных месторождений и характеризуется затухающей добычей, которая в ближайшие несколько лет начнет сокращаться. Западная Сибирь с ее Ханты-Мансийским и ЯмалоНенецким округами остается центральными районами добычи в России. Она стоит в одном ряду с такими крупнейшими нефтегазовыми бассейнами, как Персидский и Мексиканский заливы, Сахара и Аляска. Большинство из месторождений начали разрабатываться еще в советское время. Перспективные извлекаемые запасы этого полезного ископаемого Российской Федерации на 1.01.2015 г. составляли 18340,1 млн тонн. В 2017 году Россия возглавила ряд стран, где открыли новые месторождения нефти. В России таких месторождений найдено восемь, два из которых расположены в Западно-Сибирском бассейне, а остальные в Волго-Уральском бассейне [21;26].

Добычу нефти в стране осуществляют более 240 нефтегазодобывающих организаций. 11 нефтедобывающих холдингов обеспечивают более 95 \% всего объема добычи. За все время существования демократической России на ее территории не было построено ни одного нефтеперерабатывающего завода. Степень износа отечественных нефтеперерабатывающих заводов составляет $65 \%$, а загрузка составляет менее $80 \%$. Только у «Лукойла» коэффициент загрузки мощностей приблизился к отметке в 95 \%, а принадлежащий «Сургутнефтегазу» Киришский нефтеперерабатывающий завод работает на пределе мощности с загрузкой почти 100 \%. На сегодняшний день в России можно выделить нескглько крупных нефтекомпаний. «Газпромнефть» ориентируется, главным образом, на финансовый результат, и в 2017 году «Газпром» находится на 8 месте среди нефте- и газодобывающих компаний по всему миру (с до- ходом 108,5 млрд долл. США в год). А так же «Роснефть», которая находится на 9 месте среди нефте- и газодобывающих компаний (доход - 94,94 млрд долл. США в год). «Газпром» имеет потенциал привлекать из нескольких направлений крупных клиентов, таких как Германия и Турция, в том числе при сезонных колебаниях спроса [25]. По величине контролируемых нефтяных запасов «Лукойл» входит в число крупнейших компаний мира. Деятельность анализируемых корпораций ориентирована на приоритеты в данной области относительно повышения экономического эффекта по добыче и максимального использования скважин, ресурсному сбережению, а так же социальной .обеспеченности сотрудников. Управленческий аппарат имеет поддержку со стороны как государственных так и региональных структур например «Роснефть»и «Татнефть», «Башнефть»). Эти представители нефтяной отрасли сильно уступают и по финансовой эффективности, и по отраслевым показателям [24; 32]. Несмотря на это, российские компании (за исключением «Лукойла») производят значительно меньше нефти, чем западные. Основными причинами сокращения производства считается дефицит финансовых средств для инвестиций, неразвитость экспортной инфраструктуры России и низкий внутренний спрос в стране на продукцию отрасли. Вместе с тем, более низкие, чем на Западе, темпы разработки имеющихся запасов (на территории России) способны обеспечить значительно большую продолжительность их эксплуатации [9; 14; 19; 27$].$

Производство нефти в России по сравнению с зарубежными странами. Среди производителей нефти можно выделить три ключевых игрока: ОПЕК (OPEC - Organization of Petroleum Exporting Countries, Организация стран-экспортеров нефти), Россию и США, на долю которых приходится добыча более $69 \%$ нефти (более 67 \% всех жидких углеводородов) в мире. Современную Россию относят к числу крупнейших мировых производителей нефти. Здесь добывается более 12 \% нефти от мировой добычи. Добыча нефти в России позволила стране встать в один ряд с крупнейшими производителями этого важнейшего топливного ресурса, а по итогам 2016 года - даже крупнейшим. Главным конкурентом яв- 


\section{ЭКОЛОГИЯ И ПРИРОДОПОЛЬЗОВАНИЕ}

ляется Саудовская Аравия. Известно, что наиболее низкая себестоимость добычи у Саудовской Аравии (и многих других членов Опек) и оценивается в районе 3-5 долларов за баррель. Выше она в России и после девальвации оценивалась до 20 долларов для трудноизвлекаемых и шельфовых проектов, а для остальных месторождений в диапазоне 415 долларов за баррель [20]. И значительно дороже нефть обходится сланцевым компаниям США. Себестоимость добычи сланцевой нефти на месторождении Баккен (крупнейшем сланцевом месторождении в США) составляет от 42 долларов за баррель, для некоторых месторождений она оценивается в 28 долларов. Большинство стран ОПЕК и Россия занимают лидирующие позиции за счет больших запасов традиционной нефти, низкой себестоимости, а также эффекта масштаба, являясь получателями природной ренты. Их добыча рентабельна практически при любых ценах на нефть и вытеснение их с нефтяного рынка произойдет в последнюю очередь (только при тотальном отказе от нефти). С другой стороны, добыча в США и Канаде, связанная во многом с разработкой сланцевой нефти, битуминозных песков, сверхтяжелой нефти и шельфовых проектов, - высокотехнологична и дорогостояща. Развитие этих проектов, рентабельно при высоких ценах на нефть, однако их издержки постепенно снижаются; данный вид доходов скорее относится к технологической, а не природной ренте. Предпосылки такой ситуации созданы институционально (привлекательный бизнес климат, стимулирование к инновациям). Именно эти компании, перспективные в условиях высоких цен на энергоносители за счет своей многочисленности, мобильности и эффективности в плане технологий способны обогатить рынок нефтью. Россия и страны ОПЕК имеют эффективность за счет богатых месторождений, не являющаяся продуктом инновационной деятельности, а США реализуют противоположные конкурентные преимущества инновациями со стороны бизнеса и путем создания благоприятных условий со стороны государства $[1 ; 28]$.

В России в 2015 году было добыто 11,010 тыс. бар. в сутки, из которых 10,253 нефть и конденсат (более $93 \%$ ), 0,757 — га- зоконденсат. Более 35 \% добычи осуществляет подконтрольная государству Роснефть, а более $63 \%$ приходится на три крупнейшие по добыче нефти компании в совокупности («Роснефть», «Лукойл», «Сургутнефтегаз»). Кроме доли в Роснефти Правительство РФ имеет влияние на негосударственный сектор нефтедобычи через льготное налогообложение, ограничение по перекачке нефти по сети государственной трубной монополии «Транснефть», а также неформальные рычаги, что позволяет считать нефтяную отрасль в значительной степени подконтрольной государству. Россия в 2016 году несколько раз подряд обновила постсоветский рекорд по добыче нефти начиная с марта. Но в среднем за год суточная добыча оказалась меньше, чем в 2017 году. Среднесуточная добыча сырой нефти и газового конденсата в России в октябре 2016 года увеличилась на 3,9 \% в годовом выражении до 11,204 млн баррелей нефти в день, что на $1 \%$ выше предыдущего месяца. С января по октябрь 2016 года в России было произведено нефти с газовым конденсатом 454,12 млн тонн - на 2,2 \% больше прошлогоднего показателя. Из них 1/3 пришлась на Роснефть [2].

Россия по соглашению с ОПЕК и другими нефтедобывающими странами не входящих в картель $(\mathrm{OПЕК}+)$ взяла на себя обязательство сократить добычу на 300 тыс. баррелей в сутки с уровня октября 2016 года, взятого за точку отсчета действия сделки. Россия продолжила увеличивать добычу, но с меньшим темпом - с учетом сделки ОПЕК+, с соблюдением всех соглашений. В конце 2016 году нефтедобывающие страны члены ОПЕК+ договорились сократить добычу на 1,8 млн баррелей в сутки. При этом на страны ОПЕК приходится 1,2 млнбаррелей в сутки из этого объема. Россия должна была сократить добычу на 300 тыс. баррелей в сутки. В мае 2017 года соглашение ОПЕК+ было продлено до 31 марта 2018 года [7].

Добыча нефти с газовым конденсатом в России в декабре 2017 года составила 46,322 млн тонн. Это на 2,5 \% ниже показателя за октябрь 2016 года. В октябре 2016 года добыча нефти с газовым конденсатом составила 47,494 млн тонн, а далее начался процесс сокращения добычи странами ОПЕК и госу- 
дарствами, не входящими в эту организацию. В целом за 2017 год добыча нефти с газовым конденсатом в России составила 546,800 млн тонн, что на 0,1 \% ниже аналогичного показателя 2016 года. За год в страны дальнего зарубежья было экспортировано 238,721 млн тонн нефти с конденсатом, что на $1,1 \%$ больше, чем в 2016 году [1].

Страны-члены ОПЕК политически и экономически разнородны и, соответственно, вносят разный вклад в мировое предложение нефти и уровень цен. При оценке ситуации на рынке нефти стоит отметить крупнейшего и наиболее важного члена ОПЕК - Саудовскую Аравию. Доля Саудовской Аравии в ОПЕК по добыче нефти составляет более 31 \%. Суммарная доля Саудовской Аравии, России и США в добыче нефти (а также жидких углеводородов) приближается к $40 \%$. ОПЕК в 2015 году было добыто 38,284 тыс. баррелей в сутки, из которых 34,288 нефть и конденсат (почти 90 \%), 3,996 - газоконденсат и другие жидкие углеводороды. Практически все нефтяные компании ОПЕК являются государственными или контролируются ими. ОПЕК сохранила прогноз по объему мирового спроса на нефть в 2017 году на уровне 96,38 млн баррелей в сутки. При этом ОПЕК сохранила прогноз по росту мирового спроса в 2017 г. на уровне 1,27 млн баррелей в сутки. Страны ОПЕК в ноябре 2017 году снизили добычу нефти по сравнению с октябрем 2017 г на 133,5 тыс. баррелей в сутки. Существенное падение нефтедобычи зафиксировано у Анголы - 109 тыс. баррелей в сутки, Саудовской Аравии - 45 тыс. баррелей в сутки, ОАЭ 35,5 тыс. баррелей в сутки и Венесуэлы 41,6 тыс. баррелей в сутки. Страны ОПЕК и страны, не входящие в картель в конце 2016 году договорились о сокращении своей добычи нефти на 1,8 млн баррелей в сутки, подписав соглашение по сокращению добычи. Соглашение было заключено до 31 марта 2018 г. В ноябре 2017 году участники Венского соглашения вновь приняли решение продлить венскую сделку - до конца 2018 году. Спрос на нефть стран ОПЕК, по прогнозу организации, в 2018 году составит 32,2 млн баррелей в сутки $[6 ; 11 ; 18 ; 30]$.

Способность ОПЕК увеличить производственные мощности находится - под влияни- ем государственного контроля над нефтяным сектором и геополитического - климата. Что касается инвестиций и производства в члены страны с государственным контролем над нефтяным сектором, требует от правительства финансирования других социально-экономических проекты налагают бюджетные ограничения на национальные нефтяные компании для расширения производственных мощностей [12]. Начало нашего века ознаменовано для Саудовской Аравии отсутствием инвестиций в современные технологии нефтедобывающей промышленности. Относительно большая территория позволила применять новые способы добычи нефти методом разбуривания нефтяного слоя относительно дешево это с экономической точки зрения оказалось для этой страны. Отсутствие железнодорожного транспорта заставляет осуществлять все перевозки только на автомобилях и в стране адаптирована система снабжения электроэнергией под оббьем добычи нефти. Экономический эффект созданной структуры состоит в том что страна использует на внутреннем рынке примерно 2,6 барролей нефти в день. При этом, жители этой страны по показателю потребления нефти находятся в приоритете по занимаемому месту относительно данного показателя в мире и имеет тенденцию к росту.Саудовская Аравия еще может держать добычу сырой нефти на уровне 10 млн баррелей в день, но уже в 2020 году вследствие слабой инфраструктуры и технологий добычи нефти, а так же роста населения, окажется, что Саудовская Аравия сможет выдерживать темп добычи нефти лишь в пределах от 2,5 до 6 млн баррелей в день $[10 ; 12 ; 13 ; 15 ; 20]$.

В США в 2015 году было добыто 14,006 тыс. бар в сутки, из которых 9,431 нефть и конденсат (более 76 \%), 4,575 газоконденсат и другие жидкие углеводороды. США являются третьими по добыче нефти и первыми по добыче жидких углеводородов, однако, как было отмечено ранее, в списке крупнейших по добыче представлена лишь одна компания из США. Это объясняется наличием большого количества относительно мелких компаний, занимающимся в том числе добычей сланцевой нефти, что позволило США за пять лет увеличить добычу вдвое. 


\section{ЭКОЛОГИЯ И ПРИРОДОПОЛЬЗОВАНИЕ}

В 2017 году в США добывали 9,2 млн баррелей в сутки, Саудовская Аравия добывает чуть более 10 млн баррелей в сутки, Россия 10,5 млнбаррелей в сутки. Рост добычи в США за следующий год составит 8,7 \% и этих показателей американские компании достигнут к концу 2018 года [16]. Главный источник новой нефти - материковая часть США кроме Аляски, а это в первую очередь - сланцевые месторождения [5]. При этом Саудовская Аравия и Россия не будут повышать объем добываемой нефти, поскольку они договорились о продление договоренности по снижению добычи, добавляет он. По мнению аналитика, к концу 2018 года добыча в США может составить 10,4-10,7 млн баррелей в сутки. Он не исключает также, что США могут обогнать по уровню добычи и Россию в 2019 году при условии продления сделки ОПЕК+ на 2019 год или при новом технологическом скачке в сланцевой добыче, что может сократить себестоимость производства североамериканской нефти $[9 ; 22 ; 23 ; 31]$.

В США и Канаде, в отличие от России, активно осваивается технология добычи сланцевой нефти. В России, одним из крупнейших залежей труднодоступной сланцевой нефти является Баженовская свита. Анализируемые технологии имеют возможность работы с нефтенасыщенными труднопроницаемыми породами, которые залегают ниже уровня нефтеносных горизонтов традиционных месторождений $[3 ; 4 ; 8 ; 17 ; 24 ; 29]$. Относительно анализа работы в данной области на территории других стран мира нефтедобывающие корпорации незначительно на сегодняшний момент продвинулись в добыче сланцевых углеводородов, лидерами данной технологии сегодня являются США и Канада.

\section{Заключение}

Таким образом, наиболее сильной стороной российских компаний является наличие больших запасов нефти. Однако это преимущество в значительной степени утрачивается вследствие высоких налогов и низких цен на конечную продукцию, в которых вынуждены работать российские производители. Главными недостатками компаний России считаются большая степень финансовой уязвимости и низкая эффективность производственной деятельности по сравнению с ведущими компаниями Запада. Однако, страна остается безусловным мировым лидером по добыче и экспорту нефти [21]. Обеспечение намечаемых уровней добычи и повышение эффективности нефтедобычи будут основываться на научно-техническом прогрессе в отрасли, совершенствовании методов бурения, воздействия на пласт, увеличении глубины извлечения запасов и внедрении других прогрессивных технологий добычи нефти для освоения трудноизвлекаемых запасов нефти [3; 7; 9].

Основными направлениями научно-технического прогресса России в добыче нефти являются: создание и освоение технологий и оборудования, обеспечивающих высокоэффективную разработку трудноизвлекаемых запасов нефти, совершенствование и освоение технологий сооружения и эксплуатации нефтепромысловых объектов в сложных природно-климатических условиях и увеличения нефтеотдачи, развитие технологий компьютерного проектирования и моделирования процесса разработки нефтяных месторождений. В производстве ископаемого топлива, среди наиболее важных областей исследований и разработок появляются роботизированные установки для добычи подводных и подземных углеводородов, дистанционно контролируемые и с длительными периодами автоматизированного управления, разработка технологий эффективного производства углеводородов на нетрадиционных объектах (газогидраты, нефтеносные пески, сверхтяжелая нефть) и в аномальных условиях [24; 30$]$.

Совмещая развитие технологий и внедрение инноваций с имеющимися преимуществами в виде больших запасов углеводородов, Россия сможет выдерживать конкуренцию по добыче нефти наряду со странами ОПЕК, а так же США и Канадой, в которых уже имеются технологические разработки по освоению труднодоступных месторождений нефти [24].

\section{СПИСОК ЛИТЕРАТУРЫ}

1. Добыча нефти в США по итогам прошлой недели упала на 7,9 \% - до 8,781 млн барр / сутки. Электрон. текстовые дан. - Режим доступа: https:// neftegaz.ru/news/view/164694-Dobycha-nefti-v- 
SShA-po-itogam-proshloy-nedeli-upala-na-79-do8781-mln-barrsutki (дата обращения: 04.01.2019).

2. Игнатова, О. В России снизилась добыча нефти в декабре 2017 года / О. Игнатова. - Электрон. текстовые дан. - Режим доступа: https://rg.ru/ 2018/01/02/v-rossii-snizilas-dobycha-nefti-v-dekabre2017-goda.html (дата обращения: 04.01.2019).

3. История и разоблачение саудовского чуда. - Электрон. текстовые дан. - Режим доступа: http://voprosik.net/istoriya-i-razoblacheniesaudovskogo-chuda (дата обращения: 18.01.2019).

4. Мамахатов, Т. М. Перспективы добычи сланцевой нефти за рубежом и в России. - Электрон. текстовые дан. - Режим доступа: http://rosgeoportal.ru/ association/materials/SitePages/downloads/reviews/ triz.pdf(дата обращения: 15.01.2019).

5. Перспективы развития нефтедобывающей промышленности. - Электрон. текстовые дан. Режим доступа: http:/www.protown.ru/information/ hide/hide_596.html (дата обращения: 18.01.2019).

6. Страны ОПЕК в ноябре 2017 г снизили добычу на 134 тыс.барр / сутки. А Ливия и Нигерия добычу нефти нарастили. - Электрон. текстовые дан. - Режим доступа: https://neftegaz.ru/news/view/ 167654-Strany-OPEK-v-noyabre-2017-g-snizilidobychu-na-134-tys-barrsutki.-A-Liviya-i-Nigeriyadobychu-nefti-narastili (дата обращения: 04.01.2019).

7. Суточная нефтедобыча в РФ выросла до 30-летнего пика. - Электрон. текстовые дан. - Режим доступа: http://www.oilru.com/news/554207/ (дата обращения: 10.01.2019).

8. Управление энергетической информации США. - Электрон. текстовые дан. - Режим доступа: http://www.eia.gov/beta/international/rankings/ \#?prodact=53-1\&су=2015 (дата обращения: 21.12.2018).

9. Хайрутдинов, И. А. Сравнительный анализ нефтяных отраслей России, ОПЕК и США / И. А. Хайрутдинов, О. И. Шалина // Bulletin of Science and Practice. - 2016. - № 12. - C. 237-241.

10. Alkhathlan, K. Analysis of Saudi Arabia's Behavior Within OPEC and the World Oil Market / K. Alkhathlan, D. Gately, M. Javid // Energy Policy. 2014. - Vol. 64. - P. 209-225.

11. Ansari, D. OPEC, Saudi Arabia, and the Shale Revolution: Insights from Equilibrium Modelling and Oil Politics / D. Ansari // Energy Policy. - 2017. Vol. 111. - P. 166-178.

12. Barros, C. P. An Analysis of Oil Production by OPEC Countries: Persistence, Breaks, and Outliers / C. P. Barros, L. A. Gil-Alana, J. E. Payne// Energy Policy. - 2011. - Vol. 39, № 1. - P. 442-453.

13. Behar, A. OPEC vs US Shale: Analyzing the Shift to a Market-Share Strategy / A. Behar, R.A. Ritz // Energy Econ. - 2017. - Vol. 63. - P. 185-198.

14. Benedictow, A., Oil Dependency of the Russian Economy: An Econometric Analysis
/ A. Benedictow, D. Fjærtoft, O. Løfsnæs // Economic Modelling. - 2013. - Vol. 32. - P. 400-428.

15. Current Status and Potential of Bioenergy in the Russian Federation / Z.B. Namsaraev, P.M. [et al.] // Renewable and Sustainable Energy Rev. - 2018. Vol. 81, no. 1. - P. 625-634.

16. Greene, L. D. S. Oil Dependence 2014: Is Energy Independence in Sight? / L. D. Greene, C. U. Liu // Energy Policy. - 2015. - Vol. 85. - P. 126-137.

17. Hallock, J. L. Jefferson Forecasting the Limits to the Availability and Diversity of Global Conventional Oil Supply: Validation / J. L. Hallock, W. Wu, C. S. Hall // Energy. - 2014. - Vol. 64, № 1. - P. 130-153.

18. Huntington, H. G. Measuring Oil Supply Disruptions: a Historical Perspective / H. G. Huntington // Energy Policy. - 2018. - Vol. 115. - P. 426-433.

19. Korppoo, A. Russian Associated Petroleum Gas Flaring Limits: Interplay of Formal and Informal Institutions / A. Korppoo // Energy Policy. - 2018. Vol. 116. - P. 232-241.

20. Lin, B. Will Disruptions in OPEC Oil Supply Have Permanent Impact on the Global Oil Market? / B. Lin, O. E. Omoju, J. U. Okonkwo// Renewable and Sustainable Energy Rev. - 2015. - Vol. 52. - P. 1312-1321.

21. Mareš, M. Oil and Natural Gas in Russia's Eastern Energy Strategy: Dream or Reality? / M. Mareš, M. Laryš // Energy Policy. - 2012. - Vol. 50. - P. 436-448.

22. OPEC Annual Statistical Bulletin 2016. Электрон. текстовые дан. - Режим доступа: http:// www.opec.org/opec_web/static_files_project $/ \mathrm{media} /$ downloads/publications/ASB2016.pdf(дата обращения: 21.12.2017).

23. Pierk, S. Structures of Mobilization and Resistance: Confronting the Oil and Gas Industries in Russia / S. Pierk, M. Tysiachniouk // Extract. Industr. Soc. - 2016. - Vol. 3, no. 4. - P. 997-1009.

24. Proskuryakova, L. Energy Technology Foresight 2030 in Russia: An Outlook for Safer and More Efficient Energy Future/ L. Proskuryakova, S. Filippov // Energy Procedia. - 2015. - Vol. 75. - P. 2798-2806.

25. Ranking of the Global Top 10 Oil and Gas Companies in 2017, Based on Revenue (in billion U.S. dollars). - Электрон. текстовые дан. - Режим доступа: https://www.statista.com/statistics/272710/top-10oil-and-gas-companies-worldwide-based-on-revenue (дата обращения: 10.01.2018).

26. Russia Led the World for Oil and Gas Discoveries in Q3 2017, GlobalData Reports. - Электpoн. текстовые дан. - Режим доступа: http:// www.worldoil.com/news/2017/12/20/russia-led-theworld-for-oil-and-gas-discoveries-in-q3-2017globaldata-reports (дата обращения: 10.01.2018).

27. Russian Manufacturing Production Capacity: Primary Trends and Structural Characteristics / V. Salnikov [et al.] // Rus. J. Econ.2017. - Vol. 3. - P. 240-262. 
28. Soeder, D. J. The Successful Development of Gas and Oil Resources from Shales in North America / D. J. Soeder // J. Petrol. Sci. Eng. - 2018. - Vol. 163. P. 399-420.

29. Struchkov, A. The Challenges of Waxy Oil Production in a Russian Oil Field and Laboratory Investigations / A. Struchkov, M. K. Rogachev // J. Petrol. Sci. Eng. - 2018. - Vol. 163. - P.91-99.

30. The Peak of the Oil Age - Analyzing the World Oil Production Reference Scenario in World Energy Outlook 2008 / K. Aleklett [et al.] // Energy Policy. - 2010. - Vol. 38. - P. 1398-1414.

31. Vatansever, A. Is Russia Building Too Many Pipelines? Explaining Russia's Oil and Gas Export Strategy / A. Vatansever // Energy Policy. - 2017. Vol. 108. - P. 1-11.

32. Voskoboynikov, I. B. Sources of Long Run Economic Growth in Russia Before and After the Global Financial Crisis / I. B. Voskoboynikov // Rus. J. Econ. 2017. - Vol. 3, № 4. - P. 348-365.

\section{REFERENCES}

1. Dobycha nefti $v$ SShA po itogam proshloj nedeli upala na 7,9\%-do 8,781 mln barr/sutki [Oil Production in the United States Last Week Fell by $7.9 \%$ to 8.781 Million Barrels Per Day]. URL: https:// neftegaz.ru/news/view/164694-Dobycha-nefti-vSShA-po-itogam-proshloy-nedeli-upala-na-79-do8781-mln-barrsutki (accessed 4 January 2019).

2. Ignatova O. VRossii snizilas dobycha neftiv dekabre 2017 goda [Oil Production in Russia Decreased in December 2017]. URL: https://rg.ru/2018/ 01/02/v-rossii-snizilas-dobycha-nefti-v-dekabre-2017goda.html (accessed 4 January 2019).

3. Istorija i razoblachenie saudovskogo chuda [History and Exposure of the Saudi Miracle]. URL: http://voprosik.net/istoriya-i-razoblacheniesaudovskogo-chuda (accessed 18 January 2019).

4. Mamahatov T.M. Perspektivy dobychi slancevoj nefti za rubezhom $i v$ Rossii [Prospects for Shale Oil Production Abroad and in Russia]. URL: http://rosgeoportal.ru/association/materials/ SitePages/downloads/reviews/triz.pdf (accessed 15 January 2019).

5. Perspektivy razvitija neftedobyvajushhej promyshlennosti [Prospects for the Development of the Oil Industry]. URL: http://www.protown.ru/ information/hide/hide 596.html (accessed 18 January, 2019).

6. Strany OPEK v nojabre $2017 \mathrm{~g}$ snizili dobychu na 134 tys.barr / sutki. A Livija i Nigerija dobychu nefti narastili [OPEC Countries in November 2017 Reduced Production by 134 Thousand Barrels Per Day. And Libya and Nigeria Have Increased Their
Oil Production]. URL: https://neftegaz.ru/news/view/ 167654-Strany-OPEK-v-noyabre-2017-g-snizilidobychu-na-134-tys-barrsutki.-A-Liviya-i-Nigeriyadobychu-nefti-narastili (accessed 4 January 2019).

7. Sutochnaja neftedobycha $v$ RF vyrosla do 30-letnego pika [Daily Oil Production in Russia Rose to a 30-Year Peak]. URL: http://www.oilru.com/news/ 554207 (accessed 10 January 2019).

8. Upravlenie jenergeticheskoj informacii SShA [The Energy Information Aadministration of the United States]. URL: http://www.eia.gov/beta/ international $/$ rankings/\#? prodact $=53-1 \&$ cy $=2015$ (accessed 21 December, 2018).

9. Hajrutdinov I. A., Shalina O. I. Sravnitelnyj analiz neftjanykh otraslej Rossii, OPEK i SShA [Comparative Analysis of the Russian, OPEC and US Oil Industries]. Bull. Sci. Pract., 2016, no. 12, pp. 237-241.

10. Alkhathlan K., Gately D., Javid M. Analysis of Saudi Arabia's Behavior Within OPEC and the World Oil Market. Energy Policy, 2014, vol. 64, pp. 209-225.

11. Ansari D. OPEC, Saudi Arabia, and the Shale Revolution: Insights from Equilibrium Modelling and Oil Politics. Energy Policy, 2017, vol. 111, pp. 166-178.

12. Barros C.P., Gil-Alana L.A., Payne J.E. An Analysis of Oil Production by OPEC Countries: Persistence, Breaks, and Outliers. Energy Policy, 2011, vol. 39, no. 1, pp. 442-453.

13. Behar A., Ritz R.A. OPEC vs US Shale: Analyzing the Shift to a Market-Share Strategy. Energy Econ, 2017, vol. 63, pp. 185-198.

14. Benedictow A., Fjærtoft D. Løfsnæs O. Oil Dependency of the Russian Economy: An Econometric Analysis. Econ. Model, 2013, vol. 32, pp. 400-428.

15. Namsaraev Z.B., Gotovtsev P.M., Komova A.V., Vasilov R. Current Status and Potential of Bioenergy in the Russian Federation. Renewable and Sustainable Energy Rev., 2018, vol. 81, no. 1, pp. 625-634.

16. Greene L.D., Liu C.U.S. Oil Dependence 2014: Is Energy Independence in Sight? Energy Policy, 2015, vol. 85, pp. 126-137.

17. Hallock J.L., Wu W., Hall C.S. Jefferson Forecasting the Limits to the Availability and Diversity of Global Conventional Oil Supply. Energy, 2014, vol. 64, no. 1, pp. 130-153.

18. Huntington H.G. Measuring Oil Supply Disruptions: a Historical Perspective. Energy Policy, 2018, vol. 115, pp. 426-433.

19. Korppoo A. Russian Associated Petroleum Gas Flaring Limits: Interplay of Formal and Informal Institutions. Energy Policy, 2018, vol. 116, pp. 232-241.

20. Lin B., Omoju O.E., Okonkwo J.U. Will Disruptions in OPEC Oil Supply Have Permanent Impact on the Global Oil Market? Renewable Sustainable Energy Rev., 2015, vol. 52, pp. 1312-1321. 
21. Mareš M., Laryš M. Oil and Natural Gas in Russia's Eastern Energy Strategy: Dream or Reality? Energy Policy, 2012, vol. 50, pp. 436-448.

22. OPEC Annual Statistical Bulletin 2016. URL: http://www.opec.org/opec_web/static files project/media/downloads/publications/ASB2016.pdf (accessed 21 December, 2017).

23. Pierk S., Tysiachniouk M. Structures of Mobilization and Resistance: Confronting the oil and gas industries in Russia. The Extract. Industr. Soc., 2016, vol. 3, no. 4, pp. 997-1009.

24. Proskuryakova L., Filippov S. Energy Technology Foresight 2030 in Russia: an Outlook for Safer and More Efficient Energy Future. Energy Procedia, 2015, vol. 75, pp. 2798-2806.

25. Ranking of the Global Top 10 Oil and Gas Companies in 2017, Based on Revenue (in Billion U.S. Dollars). URL: https://www.statista.com/ statistics/272710/top-10-oil-and-gas-companiesworldwide-based-on-revenue/ (accessed 10 January 2018).

26. Russia Led the World for Oil and Gas Discoveries in Q3 2017, Global Data Reports. URL: http:/www.worldoil.com/news/2017/12/20/russia-led- the-world-for-oil-and-gas-discoveries-in-q3-2017globaldata-reports (accessed 10 January 2018).

27. Salnikov V., Galimov D., Mikheeva O.A., et al. Russian Manufacturing Production Capacity: Primary Trends and Structural Characteristics. Rus. J. Econ., 2017, vol. 3, pp. 240-262.

28. Soeder D.J. The Successful Development of Gas and Oil Resources from Shales in North America. J. Petrol. Sci. Eng., 2018, vol. 163, pp. 399-420.

29. Struchkov A., Rogachev M.K. The Challenges of Waxy Oil Production in a Russian Oil Field and Laboratory Investigations. J. Petrol, Sci. Eng., 2018, vol. 163, pp. 91-99.

30. Aleklett K., Höök M., Jakobsson K., et al. The Peak of the Oil Age-Analyzing the World Oil Production Reference Scenario in World Energy Outlook 2008. Energy Policy, 2010, vol. 38, pp. 1398-1414.

31. Vatansever A. Is Russia Building Too Many Pipelines? Explaining Russia's Oil and Gas Export Strategy. Energy Policy, 2017, vol. 108, pp. 1-11.

32. Voskoboynikov I.B. Sources of Long Run Economic Growth in Russia Before and After the Global Financial Crisis. Rus. J. Econ., 2017, vol. 3, no. 4, pp. 348-365.

\section{Information About the Authors}

Mikhail P. Lyabin, Candidate of Sciences (Chemistry), Associate Professor, Department of Bioengineering and Bioinformatics, Volgograd State University, Prosp. Universitetsky, 100, 400062 Volgograd, Russian Federation, dollaps@mail.ru.

Natalia A. Borozdina, Student, Department of Bioengineering and Bioinformatics, Volgograd State University, Prosp. Universitetsky, 100, 400062 Volgograd, Russian Federation, nata-lia.borozdina2016@yandex.ru.

Margarita V. Postnova, Doctor of Sciences (Biology), Senior Researcher, Head of the Department of Bioengineering and Bioinformatics, Volgograd State University, Prosp. Universitetsky, 100, 400062 Volgograd, Russian Federation, postnova@volsu.ru.

Alexey I. Bolkunov, Candidate of Sciences (Agriculture), Associate Professor, Department of Bioengineering and Bioinformatics, Volgograd State University, Prosp. Universitetsky, 100, 400062 Volgograd, Russian Federation, ruspole2009@ya.ru.

Sergey P. Butko, Senior Lecturer, Department of Tactical Special Training, Volgograd Academy of the Ministry of Internal Affairs of the Russian Federation, Istoricheskaya St., 130, 400089 Volgograd, Russian Federation, butko_sergey@mail.ru.

Alina K. Postnova, Student, Department of Ecology and Nature Management, Volgograd State University, Prosp. Universitetsky, 100, 400062 Volgograd, Russian Federation, postnowa3@gmail.com.

\section{Информация об авторах}

Михаил Павлович Лябин, кандидат химических наук, доцент кафедры биоинженерии и биоинформатики, Волгоградский государственный университет, просп. Университетский, 100, 400062 г. Волгоград, Российская Федерация, dollaps@mail.ru.

Наталия Андреевна Бороздина, студент кафедры биоинженерии и биоинформатики, Волгоградский государственный университет, просп. Университетский, 100, 400062 г. Волгоград, Российская Федерация, natalia.borozdina2016@yandex.ru. 


\section{ЭКОЛОГИЯ И ПРИРОДОПОЛЬЗОВАНИЕ}

Маргарита Викторовна Постнова, доктор биологических наук, старший научный сотрудник, заведующий кафедры биоинженерии и биоинформатики, Волгоградский государственный университет, просп. Университетский, 100, 400062 г. Волгоград, Российская Федерация, postnova@volsu.ru.

Алексей Иванович Болкунов, кандидат сельскохозяйственных наук, доцент кафедры биоинженерии и биоинформатики, Волгоградский государственный университет, просп. Университетский, 100, 400062 г. Волгоград, Российская Федерация, ruspole2009@ya.ru.

Сергей Петрович Бутко, старший преподаватель кафедры тактико-специальной подготовки, Волгоградская академия Министерства внутренних дел Российской Федерации, ул. Историческая, 130, 400089 г. Волгоград, Российская Федерация, butko_sergey@mail.ru.

Алина Кирилловна Постнова, студент кафедры экологии и природопользования, Волгоградский государственный университет, просп. Университетский, 100, 400062 г. Волгоград, Российская Федерация, postnowa3@gmail.com 